\title{
Orbital and Intracranial Complication Resulting from Acute Rhinosinusitis: Case Report
}

\section{Complicação Orbital e Intracraniana Devido à Rinossinusite Aguda: Relato de Caso}

\author{
Luana Alves de Souza *, Raquel Crisostomo Lima Verde*, Bruno Farias Lessa **, Clara Mônica \\ Figueiredo de Lima***, Marcus Miranda Lessa****, Helio Andrade Lessa ${ }^{\star * * * * . ~}$ \\ * Resident Otorhinolaryngologist Doctor at Professor Edgard Santos University Hospital - UFBA $-2^{\text {nd }}$ year. \\ ** Resident Otorhinolaryngologist Doctor at Professor Edgard Santos University Hospital - UFBA - ${ }^{\text {rd }}$ year. \\ **** Otorhinolaryngologist Doctor. \\ **** Doctor, Otorhinolaryngologist Doctor. Member researcher at Professor Edgard Santos University Hospital - UFBA's Otorhinolaryngology and Immunology Department. \\ ****** Doctor, Otorhinolaryngologist Doctor. Professor and Head of Professor Edgard Santos University Hospital's Otorhinolaryngology Department. \\ Institution: Otorhinolaryngology Department - Professor Edgard Santos University Hospital - Federal University of Bahia (UFBA). \\ Salvador/BA - Brazil. \\ Mailing address: Luana Alves de Souza - Rua Clemente Ferreira, 139 - Apto 201 - Canela - Salvador / BA - Brazil - ZIP Code : $40110-200$ - Cell phone: \\ (+55 71) 9606-2333 - Email: lua_goias@hotmail.com \\ Article received on August 6, 2009. Article approved on December 14, 2009
}

\section{SUMMARY}

Introduction:

Case report:

Final commentaries:

Among the rhinosinusitis complications, the orbital are the most frequent ones, occurring mostly in the youngsters and children. Simultaneous complications involving the intracranial orbit and space are extremely rare, but they must be severely treated for they have a high rate of morbidity and mortality. In this work, the authors report a case of a patient who appeared to have preseptal cellulites and epidural abscess, in the form of simultaneous complications of an acute rhinosinusitis. In the patient of this case, choice was made for a clinic treatment associated with a nasosinusal endoscopic surgery and neurosurgical drainage of the intracranial abscess. CT was enough to achieve the diagnosis of this case.

However, it is recommended that, in cases where patients have rhinosinusitis complications, an extensive intracranial investigation needs to be deepened even when this is not so evident in the beginning. Given the polymicrobial nature of these infections, an aggressive culture-guided antibiotic therapy and a multidisciplinary follow-up significantly increase the likelihood of success.

Keywords: orbital cellulites, sinusitis, epidural abscess.

\section{RESUMO}

Introdução:

Relato do Caso:

Comentários Finais:

Dentre as complicações da rinossinusite, as orbitárias são as mais frequentes, e estas, ocorrem na maioria dos casos entre jovens e crianças. Complicações simultâneas envolvendo a órbita e o espaço intracraniano são extremamente raras, mas devem ser tratadas agressivamente pois oferecem alta taxa de morbidade e mortalidade.

Neste trabalho, os autores relatam um caso de um paciente que se apresentou com celulite pré-septal e abscesso epidural, como complicações simultâneas de uma rinossinusite aguda. No paciente deste estudo, optou-se pelo tratamento clínico associado à cirurgia endoscópica nasossinusal e drenagem neurocirúrgica do abscesso intracraniano. A TC foi suficiente no caso apresentado para a realização do diagnóstico.

Recomenda-se entretanto, que nos casos de pacientes com complicações da rinossinusite, a investigação da extensão intracraniana seja aprofundada, mesmo quando esta, a princípio não seja tão evidente. Dada a natureza polimicrobiana dessas infecções, uma antibioticoterapia agressiva guiada por cultura e um acompanhamento por equipe multidisciplinar, aumentam consideravelmente as chances de sucesso.

Palavras-chave: celulite orbitária, sinusite, abscesso epidural. 


\section{INTRODUCTION}

Rhinosinusitis is the most frequent acute and chronic infection in otorhinolaryngology and it can be described as an inflammation of the nasosinusal mucosa (1). The introduction of several efficient antibiotics against the nasosinusal infections has expressively contributed to reduce the incidence of rhinosinusitis $(2,3)$. If they are not promptly diagnosed and correctly treated, these complications can induce visual irreversible alterations, bone impairment, important neurologic impairments, and even death $(2,4)$.

Among these complications, the orbital are the most frequent ones, occurring mostly in the youngsters and children. This is due to anatomic factors and infections of the upper respiratory tract. Orbital cellulites are one of these complications shown by edema and palpebral erythema, local pain, and it can evolve with exophthalmos and restrain the ocular movement $(5,6,7)$.

However not so frequent, the intracranial complications have a high rate of lethality (between 10\% and $20 \%$ of the cases), requiring a special attention. The most frequent intracranial complications are: meningitis, epidural abscess, subdural empyema, venous sinus thrombosis, and brain abscess. In literature, however, there is no agreement about the prevailing order of each of these complications $(3,4,8)$. Simultaneous complications between the orbit and intracranial space are extremely rare, but they must be strongly treated because they can risk vision and have a high rate of mortality (4).

In this work, we will present the case report of a patient who appeared to have preseptal cellulites and epidural abscess as simultaneous complications of an acute rhinosinusitis.

\section{Case Report}

13-year-old male patient searched for emergency ophthalmology services, claiming to have strabismus and red eye for 3 months. His mother mentioned that, 3 months earlier, the patient started showing erythema in left periorbital area followed by ipsilateral exophthalmos some days later. He denies about fever in the period and mentions infrequent occasions of bleeding rhinorrhea. He did not show any relevant data regarding medical and familiar history.

At the ophthalmologic examination, he showed a slight exophthalmos, inferior dystopia, upper eyelid edema and inflammatory signs in his left eye. Bilateral visual acuity was normal. Computed tomography (CT) was performed on brain and paranasal sinuses, and it was found an area

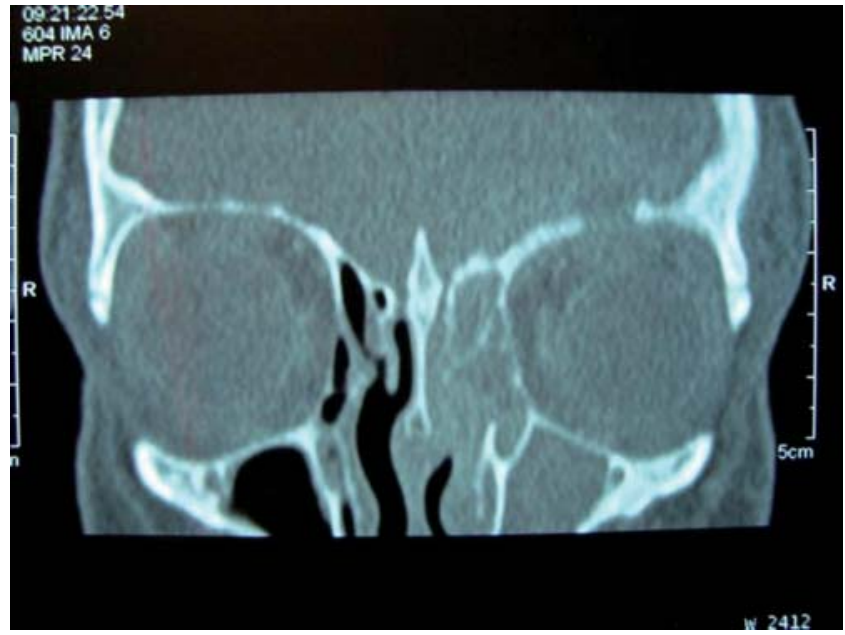

Figure 1. Computed tomography of paranasal sinuses (coronal cutting with a window to the bone part) with areas with a density of soft parts, filling the maxillary sinus and the ethmoid cells completely in addition to destroying the roof of the left orbit.

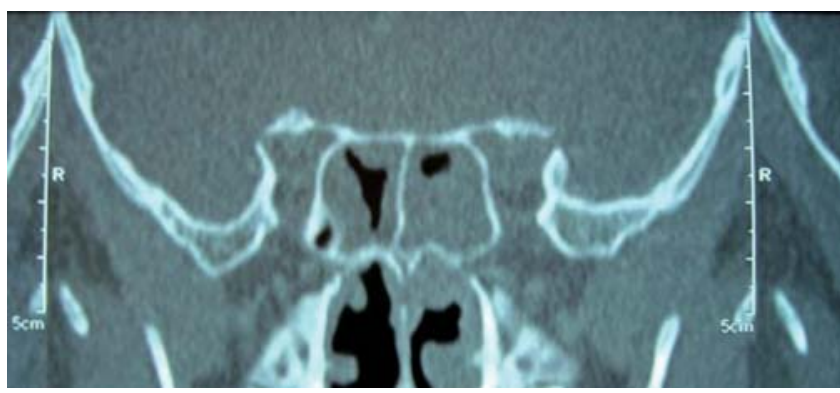

Figure 2. Computed tomography of the paranasal sinuses (coronal cutting with a window to the bone part) with areas with a density of soft parts in left sphenoid sinus and partially on the right.

with a density of soft parts filling the left maxillary sinus completely, the left ethmoid cells and, partially, the sphenoidal left and right sinuses, destruction of the roof of the left orbit, with signs of infiltration of soft parts neighboring the left ocular globe (Figures 1 and 2) and hypodense lesion, extra-axial located in the left frontal area with a measure of $4.6 \times 4.1 \mathrm{~cm}$ in its biggest axes, contrast enhancement and compressive effect by the effacement of the convexity sulci and ventricles with no alterations (Figures 3 and 4).

He was clinically interned in infirmary of the ophthalmology service to perform hemoculture followed by antibiotic therapy by parenteral via (Oxacillin $8 \mathrm{~g}$ /day, Ceftriaxone $3 \mathrm{~g} /$ day and Metronidazole $1.5 \mathrm{~g} /$ day) and neurosurgical and otorhinolaryngologist evaluations were requested. There was no bacterial growth in the submitted blood sample. 


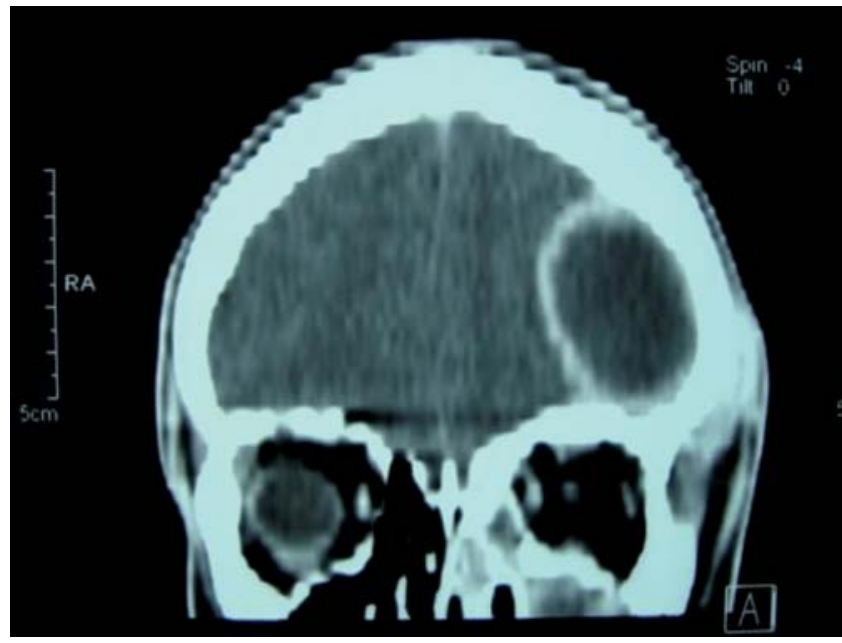

Figure 3. Computed tomography of brain, clearly showing an intracranial abscess.

In the otorhinolaryngological evaluation, nasosinusal endoscopy was performed and made it clear the presence of edema and muco-purulent secretion draining in left middle meatus. Due to the acute rhinosinusitis diagnosis complicated with preseptal cellulites and intracranial abscess, the otorhinolaryngological team decided to perform nasosinusal endoscopic surgery with maxillary sinus draining and left anterior ethmoid, which occurred without any intercurrence. Decision was also made to have neurosurgical team surgically intervening, to perform the intracranial abscess was performed. The patient was maintained at hospital with antibiotic therapy and corticotherapy was introduced before and after surgery, as well as nasal irrigation with hypertonic saline solution. The patient left hospital 15 days after surgery and continued to use oral antibiotic therapy for 6 weeks. There was no bacterial growth in the culture of the drained secretion.

Forty-five days after surgery, the patient appeared to be stable and have no complaints. Ophthalmological and neurological examinations unchanged. Control tomography with signs of left frontal craniotomy (as a consequence of the surgical intervention), with no additional findings (Figure 5).

\section{DISCUSSION}

The patient presented in this case report is a male teenager, what corroborates with the literature data. Previous studies, however, did not reach a scientific explanation about the prevalence in the male sex. As to the age group, the highest incidence of IUA (infections of upper airways) and the presence of diploic bones with a higher degree of vascularizaton in these patients' sinus walls cause this condition (9).

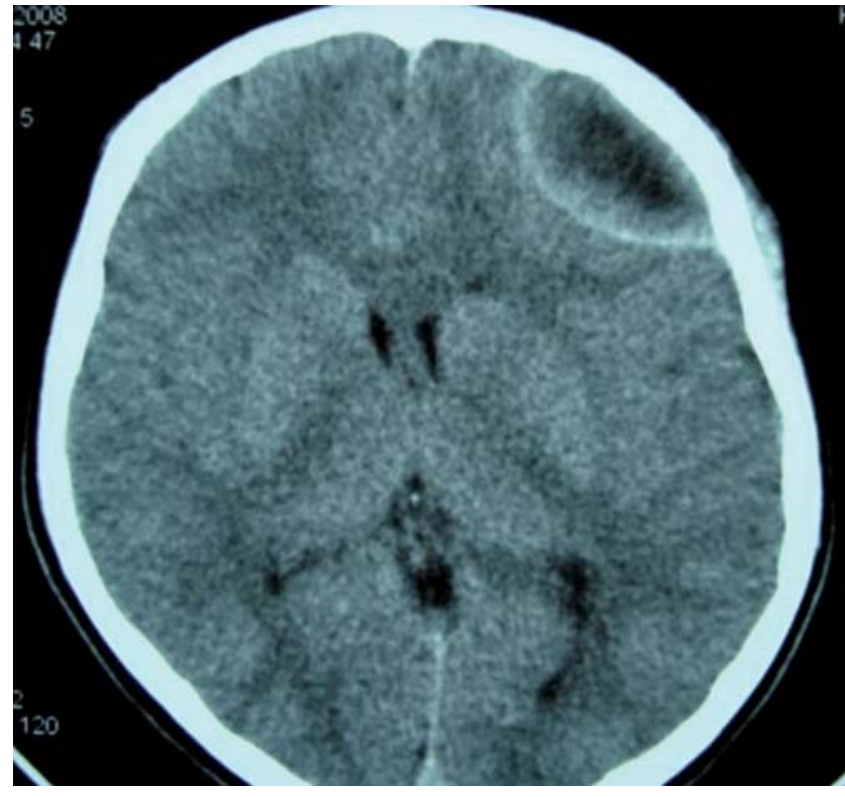

Figure 4. Computed tomography of brain with the effacement of the convexity sulci.

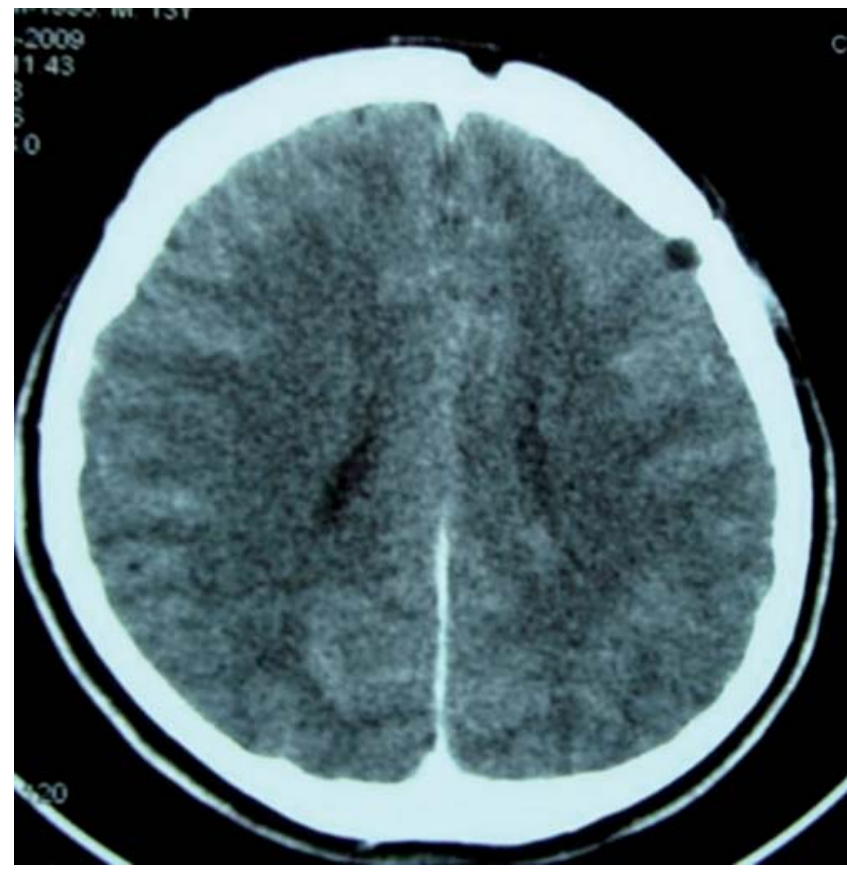

Figure 5. Computed tomography of brain 30 days after surgical draining, signs of left frontal craniotomy.

The orbital impairment secondary to rhinosinusitis is derived from the direct extension of the infection through perivascular spaces and bone dehiscences of the lamina papyracea or through deep vein thrombosis of the ophthalmic veins, facilitated by the absence of valves in this venous system $(4,5,7)$. The classification proposed by MORTIMORE and WorMaLD is based on tomographical findings, subdividing the orbital cellulites into pre- and post-septal 
(10). The preseptal cellulites, just like in our study, are manifested by ocular exophthalmos, edema and eyelid hyperemia, as well as pains when moving the eyes. The patient's pupilary reflexes and visual acuity, however, were normal.

The intracranial complications of rhinosinusitis are subsequent to either retrograde thrombophlebitis or direct extension through congenital or traumatic dehiscences, erosion of the sinusal wall or preexistent foramens. The frontal sinus is the most impaired one (46\%) followed by ethmoid, sphenoid and maxilla $(4,5,8)$. Nevertheless, CT reveals than in the reported case, there was no impairment in the frontal sinus and the intracranial dissemination occurred probably by the ethmoid sinus forming an epidural abscess. Clinically, the patients having this condition present cephalea, fever, vomits, lethargy and behavioral alterations $(4,8)$. In our case, the patient did not show these symptoms, and we warned him that he needed a screening test as a diagnostic supplement. JoNEs et col (8) found 15\% of silent intracranial involvement in patients with periorbital edema secondary to rhinosinusitis.

According to HerRmann et col (4), children at the age of 7 or older have a higher risk of simultaneously developing orbital and intracranial complications. They found in their study risk factors for intracranial complications in children served with orbital complications as a result of acute rhinosinusitis. These factors included: above 7 years of age, absence of response to initial treatment, neurological alterations, opacifications of the frontal sinus in CT, lateral or upper orbital abscess, the need to drain the orbital abscess, male sex, and African or American.

The indicated treatment usually requires a hospital commitment, multidisciplinary evaluation and intravenous antibiotic therapy of a wide spectrum. The surgical indication is essential in cases of abscess and in patients failing to respond to the initial clinical treatment $(4,7,11)$. In the patient hereof, a clinical treatment was chosen in association with the nasosinusal endoscopic surgery and the neurosurgical draining of the intracranial abscess.

\section{Final Commentaries}

CT was enough to reach a diagnosis in the present case. It is recommended, however, that in cases where patients have rhinosinusitis complications the intracranial extension should be deeply investigated, even when not so evident in the beginning. Observe that the patient of the reported case did not show any symptoms compatible with intracranial complications, therefore a special attention must be given when performing the screening test, and it can be supplemented by the magnetic resonance, when it is well indicated. Given the polymicrobial nature of these infections, an aggressive culture-guided antibiotic therapy is indicated. This therapy together with a multidisciplinary team, as in this case, significantly increases the rate of therapeutic success.

\section{BibliOgRAPHICAL REFERENCES}

1. Mitchell R, Kelly J, WagnerJ. Bilateral orbital complications of pediatric rhinosinusitis. Archives Otolaryngology Head and Neck Surgery. 2002 Aug; 128:971-74.

2. Chaudhry IA, Shamsi FA, Elzaridi E, Al-Rashed W, Al-Amri A, Al-Anezi F, Arat Y O. Outcome of treated orbital cellulitis in a tertiary eye care center in the middle east. Ophthalmology. 2007 Feb; 114:345-54.

3. Góis C R T, Pereira C U, D'Ávila J S, Melo V A. Complicações intracranianas das rinossinusites. Arquivos Internacionais de Otorrinolaringologia. 2005(9): Num 4.

4. Herrmann B W, Forsen Jr J W. Simultaneous intracranial and orbital complications of acute rhinosinusitis in children. International Journal of Pediatric Otorhinolaryngology. 2004 May; 68:619-25.

5. Reid J R. Complications of pediatric paranasal sinusitis. Pediatric Radiology. 2004 Dec; 34:933-42.

6. Vairaktaris E, Moschos M M, Baltatzis S, Kalimeras E, Vgoustidis D A, Pappas Z, Moschos MN. Orbital cellulitis, orbital subperiosteal and intraorbital abscess. Report of three cases and review of the literature. Journal of CranioMaxillofacial Surgery. 2009 Apr; 37:132-36.

7. Howe L, Jones N S. Guidelines for the management of periorbital cellulitis/abscess. Clinical Otolaryngology. 2004 Dec; 29:725-28.

8. Jones NS, WalkerJL, Bassi S, Jones T, Punt J. The intracranial complications of rhinosinusitis: can they be prevented ?. Laryngoscope. 2002 Jan; 112:59-63.

9. Gallagher R M, Gross C W, Philips C D. Suppurative intracranial complications of sinusitis. Laryngoscope. 1998; 108:1635-42

10. Mortimore S, Wormald P J. The grooter schuur hospital classification of the orbital complications of sinusitis. Journal of Laryngology and Otology. 1997 Jun; 111: 719-23.

11. Eufinger H, Machtens E. Purulent pansinusitis, orbital cellulitis and rhinogenic intracranial complications. Journal of Cranio-Maxillofacial Surgery. 2001 Jan; 29: 111-17. 